JGG 2021;69:195-207

doi: $10.36150 / 2499-6564-N 327$

\title{
Biological diagnosis of Alzheimer's disease and the issue of stigma
}

\author{
Flavio Ronchetto ${ }^{1}$, Martina Ronchetto ${ }^{2}$ \\ ${ }^{1}$ ASL T04-Ivrea Hospital, Turin, Italy; ${ }^{2}$ Techint Industrial Corporation, Milan, Italy
}

Starting from the early years of the $21^{\text {st }}$ century a shift occurred in the conceptualization of Alzheimer's disease (AD). Thanks to advances in the biomolecular field, new criteria of diagnosis and a new lexicon such as "preclinical AD", "prodromal AD", "at risk for AD" have been introduced. The disease has been reconceptualized as a slow and progressive pathological process beginning decades before clinical symptoms of dementia occurrence. Today, due to biomarkers detected in cerebrospinal fluid and on neuroimaging, there is the opportunity of a preclinical diagnosis of dementia in asymptomatic or minimally symptomatic individuals. The key characteristic of biomarkers is that they appear to reflect earlier brain changes eventually leading to clinical dementia. Originally reserved for research purposes, biological diagnosis and new lexicon seem to be now progressively included in clinical practice. If this trend is in line with the most advanced scientific achievements, on the other hand it raises some ethical concerns, mainly linked to stigma and discrimination expected toward people with a diagnosis of pre-dementia and their family caregivers. It is good to keep in mind that there is no currently certainty that asymptomatic will become symptomatic individuals and consequently further studies are needed.

The purpose of this article is to offer a historical overview and ethical discussion about the conceptual changes in Alzheimer's disease, from Alois Alzheimer to current era.

Accepted: March 16, 2021

\section{Correspondence}

Flavio Ronchetto

ASL T04 Ivrea Hospital (Personal residence: via XX settembre 1, 10082 Cuorgnè (TO))

E-mail: flavio.ronchetto@gmail.com

How to cite this article: Ronchetto F, Ronchetto M. Biological diagnosis of Alzheimer's disease and the issue of stigma. Journal of Gerontology and Geriatrics 2021;69:195-207. https://doi. org/10.36150/2499-6564-N327

(C) Copyright by Società Italiana

di Gerontologia e Geriatria (SIGG)

\section{(c) (1) (2) $\odot$}

\section{OPEN ACCESS}

This is an open access article distributed in accordance with the CC-BY-NC-ND (Creative Commons Attribution-NonCommercial-NoDerivatives 4.0 International) license. The article can be used by giving appropriate credit and mentioning the license, but only for non-commercial purposes and only in the original version. For further information: https://creativecommons.org/licenses/by-nc-nd/4.0/deed.en
Key words: Alzheimer disease, biomarkers, preclinical diagnosis, caregivers, stigma

\section{INTRODUCTION}

The in vivo diagnosis as possible or probable Alzheimer's disease (AD) is generally made when clinical symptoms of dementia are fully manifest, in according with an advanced degenerative process of brain neurons ${ }^{1}$. Currently there is a growing interest of researchers to anchor in vivo $A D$ diagnosis on biomarkers (B amyloid and tau-protein) detected in cerebrospinal fluid and on neuroimaging ${ }^{2-8}$. In parallel, there is a strong movement to extend their use to medical practice because they can allow a diagnosis even before symptoms appear, thus solving the current problem of late diagnosis ${ }^{9}$.

From an ethical perspective a preclinical or prodromal diagnosis raises some concern, primarily about stigmatization of people suffering of dementia, family and caregivers ${ }^{10-15}$. Ethical debate has a theoretical background arising from the tension between two of the four principles proposed by bioethicists Beauchamp and Childress and considered by 
many as standard theoretical framework from which to analyze ethical situations in medicine: specifically, the principle of non-maleficence (primum non nocere) and of beneficence. In the case of $\mathrm{AD}$ patients, it can be translated into providing effective treatment as soon as possible ${ }^{16}$. These principles seem all the more binding in the case of a diagnosis of early AD in asymptomatic or minimally symptomatic individuals. One question is if a status of positivity of biomarkers but in absence of clinical symptoms can be considered as disease, or rather as a condition of risk for disease ${ }^{13}$. The question is relevant because it concerns the fundamental distinction between therapy and prevention: the first is for a person with disease, the second for a person without disease. A predictive diagnosis of dementia could create a group of people waiting to become patients, with an adverse psychological impact and promote their exposition to social stigma and discrimination as it often happens for people with dementia (PWD) ${ }^{15}$. In addition, to this long "waiting time " to became patients, there is no certainty that they will become so. A second reason for debate is that no current effective therapies or cure are available, and this lack raises doubts about the categorization of people as having an early phase of $A D$ dementia. It is possible that the current scarcely effective and very expensive therapies for symptomatic forms, if extended to the treatment of asymptomatic forms, would increase health expenses with the same limited impact on the presumed neuropathological process ${ }^{15}$. Finally, it should be considered that $A D$ and mixed dementias occur in the elderly population, and this age group includes different clinical phenotypes ${ }^{17}$. The general public incorrectly perceives old age as a synonym of frailty, disability and dependence by others giving it a social negative connotation, so uniformly exercising an age-related stigmatization and discrimination. A point is that the association between old age, dementia and the stigma, prejudice, discrimination is more complex and articulated when considered in relation to clinical phenotype.

The authors of this paper, focus their attention on $A D$ stigma as addressed by relevant theoretical and empirical studies. A preferential look is at the current possibility of categorizing, using biomarkers, an asymptomatic (or minimally symptomatic) person as an individual "at risk of $A D$ " and consequently anticipate stigma and its negative effects.

\section{STIGMA CONCEPT APPLIED TO ALZHEIMER'S DISEASE}

Stigma is a vibrant argument in current research in sociology and medical disability studies. According to the definition of Erwing Goffman, it is as a situation or state of being of an individual perceived as a deviation from the norm, deeply discrediting him or her within the social context ${ }^{18}$. It is a complex concept that may occur at the individual, interpersonal, family and institutional level.

Although most research on stigma has focused on gender and racial/ethnic minority, evidence reveals that stigmatization often occurs in health domain, within which the phenomenon can be defined as a process that through artificial construction of stereotypes, prejudice and discrimination affects individual or groups having different illnesses or disorders, such as AIDS, sexuality, psychiatric illness, alcoholism, and dementia ${ }^{19-29}$. The public stigmatization process causes significative adverse effects on quality of life and health of the patient, for example removing him from utilization of health and social

services and excluding him from participation in everyday life. Negative persistent stereotypes around PWD include "they're away with the fairies" or "empty shell", myths invented by general public to justify ethically unjustifiable discriminatory attitudes ${ }^{10}$.

Stigma applied to AD represents an important area for research, however it is underinvested currently and some scholars strongly emphasize the need to remedy with further studies ${ }^{10,19}$. Although, to date direct comparisons with other stigmatizing conditions are relatively rare there is evidence that the stigma towards PWD, unlike other disorders, shows higher levels of immutability and persistence, and is associated to less propensity by public to help the victim and family, also with voluntary donations, as for AIDS and cancer (see Weiner et al. ${ }^{53}$, cited by Rosin et al.) ${ }^{10}$. A main feature is that both prejudice and discriminatory behaviors, mostly due to ignorance and misinformation ${ }^{23,29}$ can be enacted by general public or health care professionals (HCPs) - so called public stigma and professional stigma, respectively - against both PWD and people close to them, as family members - so called courtesy stigma or family stigma. PWD and their family caregivers generally react with negative beliefs, emotions and behaviors towards themselves, mostly loss of self-esteem, anger, depression, blame, fear and isolation from the social context ${ }^{19}$. In the contest of dementia, perhaps even more than in other contexts, public and self-stigma are inserted in a vicious circuit of mutual maintenance and strengthening ${ }^{24}$.

\section{A MATTER OF CONFUSION}

An explanation for the $A D$ stigmatization may be that dementia in the public perception is perceived as a 
psychiatric illness, rather than as a cognitive impairment that may or may not be accompanied throughout life by psycho-behavioral symptoms, as hallucinations, delusions and psychomotor agitation. The difference between the two mental conditions is clearly proven by current diagnostic criteria for dementia requiring the exclusion of neuropsychiatric disorders. Unfortunately, in the general population exists a persistent misperception due in part to a "problem of knowledge" (sensu Thornicroft) ${ }^{23,29}$ about the essence of $A D$ and its difference with psychiatric disorders. Assimilation of the two clinical entities is compounded by the misuse of the term to indicate a person with dementia as a 'crazy' individual. There is evidence that social stigma of mental psychiatric illness in occidental countries continues to be widespread among adults and children ${ }^{24}$, and traditionally the diagnosis of psychiatric illness is accompanied by a strongly negative label by both the general public and HCPs ${ }^{30-36}$. Psychiatric patients are seen as dangerous people and/or destroyers of social norms due both the inability to conform to rules and social stimuli but also to a "lack of will" of which patients are at least partly considered responsible ${ }^{25}$. Media considerably contribute to stigmatization of persons with psychiatric illnesses. Film and print often describe typologies of people with mental illness as homicidal maniacs who need to be feared or as people having abnormal or immature perceptions of the world ${ }^{25}$.

To prove the existence of the confusion between the two mental conditions and negative effects on PWD are the findings of a survey of 627 adults in U.S. demonstrating that over a third of the interviewed participants believed very strongly that Alzheimer's disease was a mental psychiatric illness. Those who believed more strongly that Alzheimer's disease was a mental psychiatric illness rated symptoms more severely (i.e., were more stigmatizing in their perception of symptoms) than those who did not strongly believe it was a mental psychiatric illness (see Table I, at progressive number of author [8]).

The confusion between psychiatric individuals and those with dementia is not without risk being able to frustrate the efforts made for targeted anti-stigma strategies.

\section{EMPIRICAL STUDIES}

In Table I are listed the data and main findings of nine of fifteen empirical studies published from 2010 to 2019 in different countries (over 77,000 participants, including PWD, HCPs, careers and general public) having the aim to identify individual experiences, search stigmatizing attitudes in subgroups, detect public and health professional discriminatory behaviors, highlight emotional reactions and explore the barriers to helpseeking for symptoms of dementia ${ }^{36-50}$. By examining the results, it is possible to obtain a general picture of the dimension and epidemiological characteristics of the phenomenon, in particular:

1 the majority of PWD and caregivers think that stigmatization is an ongoing process in the country in which they live and many of them primarily fear discrimination ${ }^{36}$. Both subgroups frequently perceive high levels in social rejection, internalized shame, and social isolation ${ }^{45}$;

2 almost all PWD feel embarrassed as a result of their dementia and many caregivers found themselves in embarrassing situations ${ }^{50}$;

3 in the general public exists a fear of developing this disease at a certain point of life and consequently of being marginalized in social context ${ }^{49}$; the fear of labeling and discrimination are rooted in the population ${ }^{38}$;

4 a relevant part of the general public is inclined to prejudice, stereotypes and discrimination toward PWD and family caregivers ${ }^{62}$. Stigmatization attitudes also occur in HCPs ${ }^{38,39}$;

5 in general population, stigma toward PWD differs among subpopulations for age and gender, and there is a widespread opinion that dementia is a psychiatric disease ${ }^{48}$;

6 people expected a person with $A D$ would be discriminated against by employers, excluded from medical decision-making, and have his/her health insurance limited due to documentation in the medical record, a brain imaging result, or a genetic test result ${ }^{47}$;

7 stigma is a major obstacle preventing general practitioners (GPs) from being more proactive in dementia ${ }^{40}$.

\section{EMERGING AREAS OF AD RESEARCH AND THEIR CONNECTION WITH STIGMA}

With the third millennium new areas in the AD research field with a direct implication about stigma toward individual and caregivers have emerged. One area refers to the persistent lack of disease modifying treatment as a relevant trigger factor of stigmatization and other ethical concerns. Another key area refers to the biomarker-based diagnosis of preclinical AD as a cause of anticipating stigmatization ${ }^{10-15}$. This last area includes a number of ethical challenges principally related to communication, in a double context (clinical research and practice) of the "risk" of future dementia. In addition, heterogeneity of clinical phenotype of elderly population 
Table I. AD-related stigma in nine studies in different countries, from 2010 to 2019 (over 77,000 participants, including PWD, carers, HCPs/GPs and general public).

\begin{tabular}{|c|c|c|c|}
\hline $\begin{array}{l}\text { Author, year } \\
\text { [progressive } \\
\text { number] }\end{array}$ & Aim of study & $\begin{array}{l}\text { Design study/ } \\
\text { methodology }\end{array}$ & $\begin{array}{l}\text { Country of study/ } \\
\text { sample size }\end{array}$ \\
\hline $\begin{array}{l}\text { [1] Batsch, Mittelman, ADI, World Alzheimer's } \\
\text { Report } 2012^{36}\end{array}$ & $\begin{array}{c}\text { To record individual experiences of } \\
\text { stigma by PWD and family carers from } \\
\text { a global sample }\end{array}$ & On-line survey & $\begin{aligned} & 54 \text { countries } \\
& \text { in the world } \\
& N=2,500 \text { individuals }\end{aligned}$ \\
\hline $\begin{array}{l}\text { [2] ADI-World Alzheimer Report-London School } \\
\text { of Economics and Political Science } 2019{ }^{49}\end{array}$ & $\begin{array}{l}\text { To understand findings according to } \\
\text { three areas contributing to stigma: (1) } \\
\text { knowledge (problems of ignorance/ } \\
\text { misinformation); (2) attitudes (problems } \\
\text { of prejudice) and (3) behavior (problems } \\
\text { of discrimination) }\end{array}$ & Survey & $\begin{array}{l}155 \text { countries } \\
\text { in the world } \\
\mathrm{N}=60,889 \\
\text { individuals }\end{array}$ \\
\hline [3] Blay, Peluso, $2010^{37}$ & $\begin{array}{l}\text { To investigate stigma related } A D \text { and } \\
\text { variables correlated with this outcome }\end{array}$ & Cross-sectional study & $\begin{array}{c}\text { Brazil } \\
\mathrm{N}=500 \text { adults, aged } \\
18-65 \text { years }\end{array}$ \\
\hline [4] Herrmann, et al, $2017^{38}$ & $\begin{array}{l}\text { One the purposes is to examine } \\
\text { stigmatizing attitudes in various } \\
\text { subgroups }\end{array}$ & $\begin{array}{c}\text { Review of studies } \\
\text { with qualitative and/or } \\
\text { quantitative methodology }\end{array}$ & $\begin{array}{c}\text { US and Europe } \\
(\mathrm{N}=51 \text { studies }) \\
\mathrm{N}=\text { over } 9,700 \\
\text { participants }\end{array}$ \\
\hline [5] Piver et al., $2013^{39}$ & $\begin{array}{l}\text { To describe perceived stigma against } \\
\text { AD in a French population }\end{array}$ & $\begin{array}{l}\text { Stigma questionnaire, } \\
\text { cross-sectional stigma } \\
\text { assessment }\end{array}$ & $\begin{array}{c}\text { France } \\
\mathrm{N}=517 \text { adults, } \\
\text { aged } 25-75 \text { years }\end{array}$ \\
\hline [6] Phillipson et al., $2014{ }^{42}$ & $\begin{array}{c}\text { To examine sociodemographic factors } \\
\text { associated with attitudes regarding } \\
\text { dementia }\end{array}$ & $\begin{array}{l}\text { Cross-sectional, on-line } \\
\text { survey }\end{array}$ & $\begin{array}{c}\text { Australia } \\
\mathrm{N}=616 \text { individuals, } \\
\text { aged } 45-60 \text { years }\end{array}$ \\
\hline [7] Alzheimer Australia, $2017^{50}$ & $\begin{array}{c}\text { To investigate beliefs and attitudes } \\
\text { about dementia, Alzheimer's Australia } \\
\text { developed an online survey to examine } \\
\text { stigma experienced by PWD and carers, } \\
\text { as well as the general public's attitudes } \\
\text { towards PWD. }\end{array}$ & $\begin{array}{c}\text { On line survey; } \\
\text { with use of scale (Stigma } \\
\text { Impact Scale and Dementia } \\
\text { Attitudes Scale) }\end{array}$ & $\begin{array}{c}\text { Australia } \\
\mathrm{N}=1,457 \text { individuals } \\
(\mathrm{n}=44 \text { PWD; } \mathrm{N}= \\
751 \text { carers; } \mathrm{N}=662 \\
\text { general public) }\end{array}$ \\
\hline [8] Stites, Rubright, Karlawish, $2018{ }^{47}$ & $\begin{array}{c}\text { To understand the composition of } \\
\text { beliefs, attitudes, and expectations } \\
\text { about AD dementia held by the general } \\
\text { public }\end{array}$ & $\begin{array}{c}\text { Survey of random sample of } \\
\text { the general population }\end{array}$ & $\begin{array}{c}\text { US } \\
\mathrm{N}=317 \text { individuals, } \\
\text { median age } 49 \text { years }\end{array}$ \\
\hline [9] Stites, Johnson, Harkins et al., $2018^{48}$ & $\begin{array}{l}\text { To investigate how stigmatizing } \\
\text { attributions of } A D \text { differ among } \\
\text { identifiable subgroups of adults in the } \\
\text { population }\end{array}$ & $\begin{array}{l}\text { Self-reported stigmatizing } \\
\text { attributions of } A D \text { in a } \\
\text { random sample of adults in } \\
\text { the general public }\end{array}$ & $\begin{array}{l}\text { US } \\
N=627 \text { adults }\end{array}$ \\
\hline
\end{tabular}




\begin{tabular}{|c|c|c|}
\hline Subgroup(s) & $\begin{array}{l}\text { Manifestations of stigma/ } \\
\text { associated factors or effects }\end{array}$ & Main findings \\
\hline $\begin{array}{l}\text { PWD/ Family or informal } \\
\text { carers }\end{array}$ & - Perceived stigma & $\begin{array}{c}\text { Over } 75 \% \text { of participants say there are negative associations (i.e. } \\
\text { stigma) about PWD and the country their live in. The most common } \\
\text { negative association was the feeling of being marginalized by others } \\
(28 \%)\end{array}$ \\
\hline $\begin{array}{l}\text { PWD/ Caregivers/ } \\
\text { Lay public/ } \\
\text { HCPs }\end{array}$ & $\begin{array}{l}\text { - Ignorance and misinformation } \\
\text { - Prejudice } \\
\text { - Discrimination } \\
\text { (social exclusion) }\end{array}$ & $\begin{array}{l}\text { About } 80 \% \text { of the public are concerned about developing dementia } \\
\text { at some point; } 35 \% \text { of carers across the world said that they have } \\
\text { hidden the diagnosis of dementia of a family member; over } 50 \% \text { of } \\
\text { carers globally say their health has suffered as a result of their caring } \\
\text { responsibilities even whilst expressing positive sentiments about their } \\
\text { role; } 62 \% \text { of HCPs worldwide think that dementia is part of normal } \\
\text { aging; } 40 \% \text { of the general public think doctors and nurses ignore PWD }\end{array}$ \\
\hline $\begin{array}{l}\text { Individuals } \\
\text { living in community }\end{array}$ & $\begin{array}{l}\text { - Stereotype } \\
\text { - Prejudice } \\
\text { - Discrimination }\end{array}$ & $\begin{array}{l}41.6 \% \text { of participants express stereotypes, } 43.4 \% \text { prejudice, } 35,5 \% \\
\text { discrimination towards PWD }\end{array}$ \\
\hline $\begin{array}{c}\text { PWD/ HCPs/ } \\
\text { GPs/ } \\
\text { Lay public/ } \\
\text { Family and caregivers }\end{array}$ & - Stigmatizing attitudes & $\begin{array}{l}70 \% \text { reports were from developed countries; } \\
\text { stigmatization attitudes occur both HC workers and in the lay public; } \\
\text { some primary care clinicians or GPs have stigmatizing attitudes; stigma } \\
\text { burden is higher among some minority groups in US }\end{array}$ \\
\hline $\begin{array}{l}\text { Workers in health and } \\
\text { social fields/ High school } \\
\text { and college students/ } \\
\text { Retired people }\end{array}$ & $\begin{array}{l}\text { - Stereotype } \\
\text { - Prejudice } \\
\text { - Discriminations }\end{array}$ & $\begin{array}{l}\text { Interest in AD was: professional, } 48 \% \text {; related to family, } 41 \% \text {; personal, } \\
11 \% \text {. } \\
\text { Workers in health fields expressed the highest levels of stigma. Low } \\
\text { stigma was most in older people. Perceived stigma is more prevalent in } \\
\text { professional health field than the general public; the main dimensions of } \\
\text { stigma were shame and loss of self-esteem. }\end{array}$ \\
\hline Lay public & - Attitudes & $\begin{array}{c}\text { Four attitudinal factors were identified. Three were associated with } \\
\text { negative attitudes (Personal Avoidance, Fear of Labelling and Fear of } \\
\text { Discrimination) and one with more positive attitudes. Demographic } \\
\text { factors (age, sex, education) were significantly associated with some } \\
\text { attitudinal factors }\end{array}$ \\
\hline $\begin{array}{l}\text { PWD/Carers/ } \\
\text { General public }\end{array}$ & - Perceived stigma & $\begin{array}{l}94 \% \text { of PWD have encountered embarrassing as a result of their } \\
\text { dementia; } 60 \% \text { of carers have found themselves in embarrassing } \\
\text { situations, and almost } 50 \% \text { of the general public felt frustrated because } \\
\text { they were unsure of how to help people with dementia }\end{array}$ \\
\hline General population & $\begin{array}{l}\text { - Beliefs, attitudes } \\
\text { and expectations } \\
\text { about AD }\end{array}$ & $\begin{array}{l}\text { People expected a person with AD would be discriminated against by } \\
\text { employers, excluded from medical decision-making, and have his health } \\
\text { insurance limited due to documentation in the medical record, a brain } \\
\text { imaging result, or a genetic test result }\end{array}$ \\
\hline General population & $\begin{array}{c}\text { - Specific stigmatizing beliefs, attitudes, } \\
\text { and behaviors associated } \\
\text { with } A D\end{array}$ & $\begin{array}{l}\text { Analyses from a random sample of } 627 \text { adults in the U.S. general } \\
\text { population showed that stigma differed among subpopulations, } \\
\text { particularly those described by age, gender, and the belief that AD is a } \\
\text { mental illness*. } \\
\text { ( }{ }^{\star} 35 \% \text { of respondents believed very strongly that Alzheimer's disease } \\
\text { was a mental illness, and those who believed more strongly that } \\
\text { Alzheimer's disease was a mental illness rated symptoms more severely } \\
\text { than those with weaker beliefs) }\end{array}$ \\
\hline
\end{tabular}




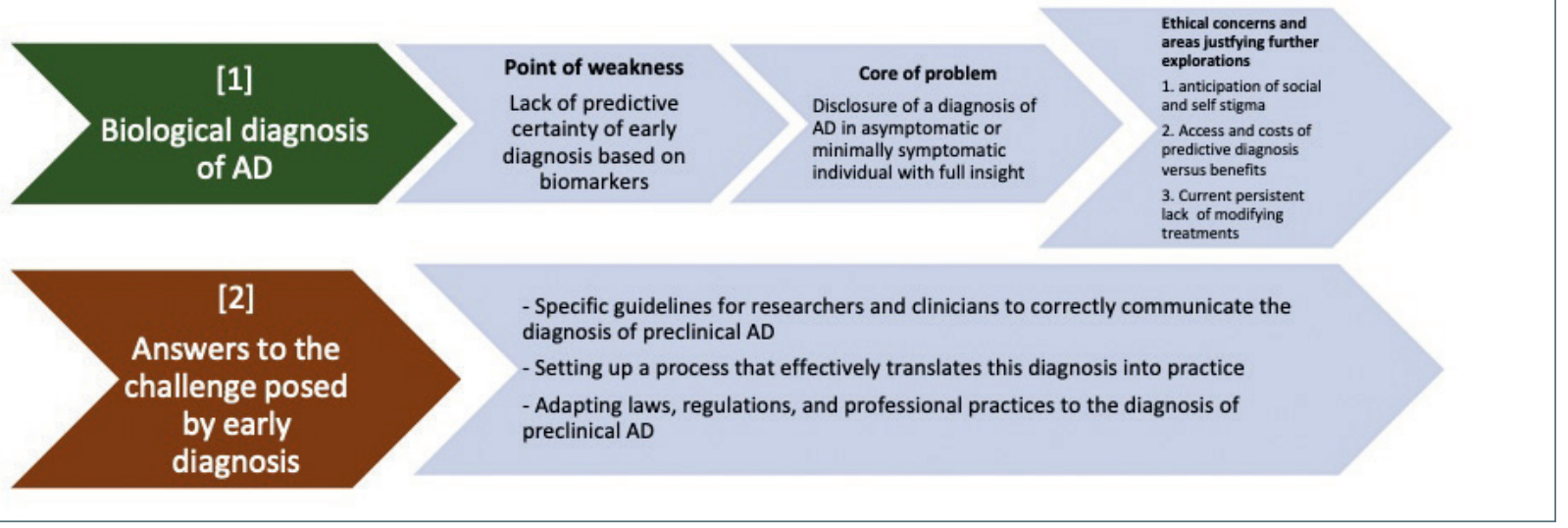

Figure 1. AD biological diagnosis and areas of ethical concerns justifying further explorations.

makes more complex, articulated and delicate the communicative approach of clinician. From the above, emerges the necessity of established multi-level guidelines to communicate the diagnosis of preclinical $A D$ (Fig. 1, box n. 2).

\section{Persistent lack of disease modifying-treatment}

Lack of disease modifying-treatment (DMT) is associated with two main ethical aspects: the first concerns the cost-benefit ratio of the current use of symptomatic drugs (as the cholinesterase inhibitor drugs and the $\mathrm{N}$ methyl-D-aspartate receptor antagonist memantine), the second being the stigma.

Current drugs have been criticized for providing insufficient benefit to justify their costs ${ }^{15}$. However, the issue is problematic because there are discrepancies in the results of cost-of-illness studies on AD ${ }^{51}$. Consequently, the ethical dilemma does not find, at present, an agreed solution. On the other hand current therapies are unable to act on the pathological substrate of the disease, whereas dementia continue to impose high societal economic burdens, due to its impact on health and social care services, families, and Governments that have the task of improving the lives of people with dementia and their caregivers.

Persistent lack of DMT or cure for AD is associated to stigma because it influences the perception by the general public, amplified by the media, that AD is a terminal illness and diagnosis of $A D$ is equivalent to a death sentence ${ }^{10}$. The social constructions of the stereotype of "living dead" contributes to diminish the social value of the person, and the tendency to avoid him/her increases ${ }^{52,53}$. As already pointed out in this article, the stigma of dementia was connected to relatively lower intent in offering help and a higher level of stability over time compared to other stigmatizing conditions such as AIDS and cancer ${ }^{53}$.
To date, in parallel to the reconceptualization of $A D$ as a biological entity, the problem of the current lack of effective drugs has taken on an even more critical connotation when considered in relation with an early diagnosis in asymptomatic or minimally symptomatic persons (see the paragraph: "The biological diagnosis of $A D$, subparagraph: "Disclosure of the diagnosis of AD to asymptomatic or minimally symptomatic person" - "Effects at social level, including health care expenses").

\section{BIOLOGICAL DIAGNOSIS}

Conceptualization of $A D$ has a history marked by the shift from an in vivo diagnosis based on clinical criteria to a diagnosis based on biological criteria and the possibility with the latter to diagnose very early stages of dementia, before it becomes symptomatic. This shift is not ethically neutral as it directly affects people's quality of life and health, for example by anticipating the stigma towards PWD and their families.

Below is a brief description of the two periods according to the ethical debate; the first period refers to the original conceptualization of $A D$, the second refers to the new conceptualization:

- First period. Until 2005, the ethical debate was focused on clinical AD diagnosis as formulated by group of scholars of the NINCDS-ADRDA (1984) ${ }^{1}$. In particular it concerned the following points ${ }^{15}$ : (1) the disclosure of the diagnosis of dementia and related consequences in terms of stigma and discrimination; (2) the cost/benefit of current symptomatic drugs in relation to different problems, as (a) the opportunity (or not) to extend their prescription to all stages of disease; (b) the low efficacy on cognitive symptoms in the severe stage of dementia, and clinical criteria to stop them, (c) the lack of efficacy on the progression or regression of the underlying neurodegenerative process; (3) the competence 
of patients to consent to research and therapy in clinical practice; (4) end-life care; (5) the involvement of the family and caregivers in the decision-making process; (6) the use of placebo in randomized clinical trial. Point 1 is a key argument where different positions collide: those in favor, those against and those emphasizing a decision based on an individualized approach. Those in favor of diagnostic disclosure appeal to moral and legal right of patients to receive a specific diagnosis. In fact, the informed patient can make decisions on therapy, diagnostic procedures, dispose of his own affairs, formulated advance directives, designate a legal representative if necessary. On the other hand, others, express serious concerns due to the fact that the clinical diagnosis is not of certainty and the prognosis is imperfect. They underline that diagnosis concerns patients in different stages of disease and different cognitive impairment who inevitably suffer a more or less serious loss of decision-making capacity and, ultimately, of competence ${ }^{15}$. Therefore, it can be argued that currently disclosing the diagnosis of $\mathrm{AD}$ to a patient remains controversial also considering that there is significant self- and public stigma associated with this diagnosis. It should also be considered that dementia is a disease with a high degree of emotional, psychic and physical involvement of the family and caregivers of the patients. People closest to the AD patients may experience on themselves the same negative consequences of the stigma and discrimination that affects the family member they care for ${ }^{10}$;

- Current era. More recently a new area of ethical interest has opened up in parallel with the shift from $a$ in vivo diagnosis of $A D$ based on clinical criteria to a diagnosis based on biomarkers ${ }^{10-15}$. Today a biological diagnosis of preclinical dementia can be made according to formulated parameters for research purpose, by of the working groups NIA-AA (2011) and IWG-AD (2007) $)^{2,7}$. Both these diagnostic models express a new conceptualization and lexicon of AD (as illustrated in Table II), finding its justification in the hypothesis of the amyloid cascade' ${ }^{54}$ that indicates an inevitable progression towards the direction of full decline. On the other hand, this dramatic evolution is all to be verified and hypothesis of amyloid cascade not unanimously accepted among scholars. In fact, post-mortem analysis has revealed that elderly individuals can possess extensive amyloid pathology without dementia or $\mathrm{MCl}$ and in vivo brain imaging analysis showed amyloid pathology in about to $40 \%$ of elderly people with normal cognitive functions ${ }^{55,56}$.

A diagnosis of $A D$ in asymptomatic or minimally symptomatic individual in absence of a predictive certainty brings up a series of ethical problems concerning the communication, the treatment, the competence of patient and advanced care directives, the involvement of family and caregivers ${ }^{10,13,15}$.

\section{Disclosure of the $A D$ diagnosis to asymptomatic or minimally symptomatic person}

From an ethical perspective, there is a salient difference between the disclosure of a diagnosis of $A D$ in a symptomatic person and the disclosure of "a risk" of a hypothetical future dementia in an asymptomatic or minimally symptomatic person with full insight ${ }^{15}$. The question, when translated from research field to the clinical practice, is whether a physician in contact with a fully competent person with diagnosis of preclinical dementia or $\mathrm{MCl}$ or "at risk" of dementia, should adhere to a code that prescribes that diagnosis must always, and in any case, be disclosed to the person or rather adopt a strategy and guidelines considering the individual,

Table II. 2011, NIA-AA and 2007, IWG-AD terminology for AD in relation with cognitive profile (from Schermer and Edo (2018/2019), mod.) ${ }^{13}$.

\begin{tabular}{|c|c|c|}
\hline Cognitive profile & NIA-AA in vivo diagnosis & $\begin{array}{c}\text { IWG-AD in vivo diagnosis } \\
\text { (Biomarkers }+ \text { ) }\end{array}$ \\
\hline (Biomarkers + )
\end{tabular}

Biomarkers detected using CSF analysis, magnetic resonance imaging (MRI) scanning and

positron emission tomography (PET) scanning.

Both the framework considers individuals with $\mathrm{MCl}$ and abnormal biomarkers having $A D$ ("MCI due to AD" for NIA-AA criteria,

and "Prodromal AD" for IWG-AD criteria), irrespective of whether their cognitive impairment is progressive and will lead to

dementia. The main difference between the two frameworks is that, according to the NIA-AA criteria one can have AD

without cognitive symptoms (preclinical AD stage 1-2) whereas, according to the IWG criteria, people without symptoms can only be labelled as "at risk for AD". 
family and social risks linked to communicating that diagnosis. The dilemma is due to the fact that term or expression adopted to communicate a diagnosis that directly or indirectly refers to a status of $A D$ dementia is not indifferent because it can have remarkable effects on two level ${ }^{13}$. Such effects can be:

1 Effects at individual level. Disclosing to a person a diagnosis of $A D$, even if it is "mitigated" by the expression "pre-clinical-AD" or "MCl due to $A D$ " or "at risk of $A D$ " can cause psychological and emotional reactions in the same way as for a clinical diagnosis of $A D$, including fear, anxiety, depression, mental distress, loss of self-esteem and self-stigmatization, catastrophic thinking, suicidal ideation, somatic problems. It is known that people with a diagnosis of $A D$, their families and caregivers experience both embarrassment and shame, being exposed to public stigma, prejudice and discrimination ${ }^{13}$. Thus, the new lexicon that preludes a hypothetical future AD dementia seems to be a starting point for stigma. Public and selfstigma and its effects could be inserted in a vicious circuit of mutual maintenance and strengthening. In this circuit there are, to our understanding, two critical areas of ethical interest: the first is the area of the anticipation of stigma, the second of selfstigma based on a (mis)perception of a future dementia. Disclosing a risk status might not carry burden on the ethical principles of Beauchamp and Childress (preserving autonomy, beneficence and non-maleficence) ${ }^{16}$, but is also very likely that after disclosing a risk assessment, the status of the person changes: it becomes a "patient-in-waiting". Consequently, risk information might generate unnecessary psychological burden ${ }^{13}$.

Nonetheless, there are nuances within new $A D$ lexicon that require attention: explaining to a patient that he is at risk of developing AD dementia is different from telling he has preclinical or asymptomatic $A D$ dementia. Likewise, clarifying he has early dementia is different from explaining that the biomarkers indicate a risk of dementia within 10-15 years. Anyhow, the communication of a pre-conditions for $A D$, as mentioned above, can lead to a deleterious state of stress and uncertainty for the future. New patients are created waiting for a clinical progression that may not occur or occur a decade later or more. Labeling a person as having early $A D$ or at risk of AD can easily sentence him /her to "social death", and indirectly cause negative impact on family and caregivers ${ }^{57}$. The great complexity of the problem about diagnostic communication is linked to the fact that people have a right to known their risk, if they want to prepare for their future necessities in terms of finance and care, settling family matters, getting support and psychological preparation ${ }^{13}$;

Effects at social level: the health care expenditure. A major consequence of dementia at social level is of economic type. $A D$ is one of the most expensive diseases in old age, burdened by direct medical costs (nursing home care, medications, physician visits, hospitalizations) and non-medical care costs (home health aides, respite care, adult daycare). In addition, indirect costs due to loss of resources due to the illness (patient and caregiver's loss of productivity) associated to intangible costs related to pain and suffering endured by patients and families, and those related to deterioration of patient and caregiver quality of life. In the light of the biological conceptualization of $\mathrm{AD}$ and the communication of diagnosis are expected social effects deriving from the large proportion of the elderly population that could be categorized as "at risk" or who have early dementia. Screening tests based on biomarkers could promote a growth in current poorly effective medicalization (see paragraph "Persistent lack of disease modifyingtreatment") in an elderly population that already takes many drugs for comorbidities with an increase both of iatrogenic risk and costs for health care. The number of old adults waiting to become patients could become huge and this could reinforce public stigma, prejudice and discrimination ${ }^{13}$. The waiting patients would be perceived by lay public as old people on the way to severe dementia who dramatically increase health care costs (medical visits, monitoring with laboratory and instrumental checks, domestic help). Some scholars have estimated that future effective drug-modifying treatment administered in $\mathrm{MCl}$ due to $\mathrm{AD}$ may be potentially cost-effective given assumed treatment effects and costs, but cost savings are unlikely ${ }^{58}$. This means that a future effective DMT of preclinical dementia cases may not even lead to significant cost savings for dementia care.

\section{Predictive diagnosis, aging and clinical phenotypes}

People express predominantly negative attitudes and beliefs toward older adults, especially in comparison to their attitudes toward younger people ${ }^{59}$. In other words, there is an age-related stigma and this is above all associated with a misperception of aging.

Whereas general public incorrectly perceives old age as a synonym of frailty and disability, there is evidence that the category of older adults is not a homogeneous clinical group of persons. Although the popular tendency to homogenize the elderly seems less pronounced today, it remains a relevant problem. A cognitive defect of varying severity until overt dementia can occur both in an otherwise healthy and active person, and in a person 
with comorbidities and varying degrees of physical disability and loss of autonomy due to a range of coexisting chronic pathologies (such as cardiovascular disease, respiratory disease and metabolic disease).

The clinical heterogeneity of the elderly adds problems to the communication of the diagnosis of dementia and it is very likely that there are implications also for the communication of a predictive diagnosis. Stigma, prejudice and discrimination towards individuals with marks of cognitive decline due to $A D$ or "at risk" can favor individual emotions and reactions at least partly dependent on the clinical phenotype. As an example, a predictive diagnosis of $A D$ could accentuate or trigger anxiety, psychological depression and catastrophic thinking in individuals already suffering from other diseases or in unstable psychophysical balance ${ }^{59}$. The emotional reactions and the withdrawal from social life in turn can reinforce prejudice and social discrimination.

\section{Guidelines to communicate the diagnosis of preclinical $A D$}

Current international guidelines and recommendations for physicians advise against the use of biomarkers/ predictive test of $A D$ dementia in asymptomatic or minimally symptomatic individuals (Tab. III) ${ }^{61-66}$. However, some scholars underline the need to develop empirically based guidelines that address the ethical and social strategies for risk communication of dementia prediction by genetic tests and biomarkers, because the guidelines do not address the new developments sufficiently ${ }^{60}$. Guidelines on risk disclosure should be developed by involving various stakeholders and should be informed by socio-empirical studies involving general public needs and opinions regarding risk communication. Figure 1 schematically shows the ethical issues associated with biological diagnosis and the possible responses to the challenge posed by a preclinical/ predictive diagnosis of dementia.

\section{DISCUSSION AND CONCLUSIONS}

The possibility of a diagnosis of $A D$ via biomarkers represents an important step for research in preventive strategies and future DMT ${ }^{67}$. However, we have seen that ethical concerns exist about the probability of stigma and discrimination due to cases of anticipation of the diagnosis of dementia in the current absence of a certainty of evolution towards full-blown dementia ${ }^{10-15}$. A central point of interest is that, to date, attempts to mitigate the stigma toward PWD has been made formulating international anti-stigma multilevel recommendations ${ }^{24,36,61-66,68}$, but the recent (bio)scientific developments open the way to new areas for future research about stigma associated with all stages of disease, including earlier stages. The biological extension of the

Table III. Synoptic table of guidelines/recommendations for use of biomarkers/predictive test of Alzheimer's dementia in asymptomatic or minimally symptomatic individuals (from Alpinar-Sencan, Schicktanz, 2020) ${ }^{60}$.

\begin{tabular}{|c|c|}
\hline Country & Guidelines/recommedations \\
\hline United States ${ }^{63}$ & $\begin{array}{l}\text { Use of biomarkers not is recommended for clinical diagnosis } \\
\text { It is recommended that people with } \mathrm{MCl} \text { should be carefully monitored } \\
\text { For patients suspected to have } \mathrm{MCl} \text {, clinicians who lack the necessary experience should refer these patients to a } \\
\text { specialist with experience in cognition } \\
\text { Physician should inform the individuals about scientific limits of tests }\end{array}$ \\
\hline Canada ${ }^{64}$ & $\begin{array}{l}\text { Use of biomarkers not is recommended for clinical diagnosis } \\
\text { Persons with } \mathrm{MCl} \text { should be carefully monitored } \\
\text { People with } \mathrm{MCl} \text { should be encouraged to follow appropriate lifestyles } \\
\text { Persons with } \mathrm{MCl} \text { should not be labelled as having early } \mathrm{AD}\end{array}$ \\
\hline Germany ${ }^{65,66}$ & $\begin{array}{l}\text { Use of biomarkers not is recommended for clinical diagnosis } \\
\text { If person with } \mathrm{MCl} \text { asks for risk assessment, physician can direct the person and family to research centers } \\
\text { Physician should inform the individuals about scientific limits of tests, possibility and treatment options } \\
\text { Handling to biomarkers is left to physicians }\end{array}$ \\
\hline Italy ${ }^{61,62}$ & $\begin{array}{l}\text { Amyloid-PET is not recommended for asymptomatic individuals, even in the presence of family history of dementia and / } \\
\text { or who have one or two } \varepsilon 4 \text { alleles of apolipoprotein E (APOE4) } \\
\text { CSF biomarkers should not be considered a routine test } \\
\text { The study of CSF biomarkers in cognitively normal subjects or in patients who meet the criteria for probable AD is not } \\
\text { recommended } \\
\text { Use of biomarkers in individuals asymptomatic or patients with subjective cognitive impairment, which do not satisfy the } \\
\text { criteria for } \mathrm{MCl} \text {, or in individuals at risk (e.g. mutation carriers genetics, family history of Alzheimer's, ApoE4) should be } \\
\text { limited to the scope of research }\end{array}$ \\
\hline
\end{tabular}

MCl: mild cognitive impairment; CSF: cerebrospinal fluid; amyloid-PET: amyloid-positron emission tomography scanning 
diagnostic spectrum involves anti-stigma strategies originally tailored for cases of clinical (symptomatic) dementia and the emergence of new diagnostic categories presents an ethical challenge. According to more recent literature, four key areas for possible anti-stigma interventions can be identified ${ }^{10-15}$.

First area, consists in the fight against negative stereotypes of $A D$ due to persistent lack of $D M T$ and preventive treatments, for example the stereotype that PWD are "unable to contribute to society" ${ }^{49}$. Rosin et al. (2020) ${ }^{10}$, suggest a strategy of "contact-based approach", via a virtual (video) platform or face-to- face, that has proven to be effective in countering the stigma against mental illness ${ }^{69}$. This approach seems to be more effective than educational intervention (against self and public stigma) alone. It is likely that in vivo contact-based approaches that could reduce AD stigma among community members could be promoted via special programs (programs of arts participation, such as "Alzheimer's Poetry Project", "Meet Me at MoMA" and others) which use AD specific knowledge to allow $\mathrm{AD}$ patients, caregivers, and members of the community to interact in creative ways ${ }^{70,71}$. Another strategy, is based on "person centered care", focused on individual and interpersonal relationship ${ }^{72}$. Thanks to this strategy, it is possible to include people with cognitive impairment in the decision-making process about their health and care, helping to improve them. By applying this methodology to all stages of the disease, it is possible to continuously reduce the stigma and increase the individual perception of autonomy ${ }^{10}$.

Second area concerns the necessity to continue the assessment of effects potentially resulting from earlier detection of conditions for $\mathrm{AD}$, such as $\mathrm{MCl}$ or at risk of $A D$. As shown in literature and illustrated in studies cited in this article, it has been observed that there is public stigma associated with the risk of psychiatric mental conditions (as psychosis) and this finding suggests that stigma may also apply to risk conditions for cognitive mental illness (as dementia) ${ }^{73}$. However, since it is easy to understand that this is a problem of correct information for the general public, it is very likely that it can be solved with an educational intervention that explains to the community that the state of risk does not mean that the person at risk will develop full-blown dementia.

Third area concerns the assessment of impact on health behaviors following disclosure of a risk for $A D$ development. The communication could stimulate the individual to adopt healthy behaviors (physical activity, diet, not smoking etc.) in order not to aggravate the course. In an analysis as part of the Risk Evaluation and Education for Alzheimer's disease (REVEAL) study, authors found that people who learn they are at high genetic risk for $A D(A P O E \varepsilon 4+)$ are motivated to engage in behaviors to reduce risk, even if the effectiveness of activities is uncertain ${ }^{74}$. This finding demonstrates the importance of educating individuals about behavioral factors protecting against dementia or increasing the risk of development and/or progression of disease. Further studies are needed to understand if the patient's education and eventually consequent adherence to changing incorrect behaviors and lifestyles is able to reduce the stigmatizing potential of diagnostic communication of risk of $A D$ or early $A D$.

Fourth area concerns the interaction between $A D$ stigma with marginalized minority populations.

In many countries, ethnic and racial minorities are underrepresented in $A D$ research including early $A D$ testing. The lack of participation is at least in part due to cultural factors, as the belief that dementia is a normal effect of aging ${ }^{10}$. This belief may explain the refusal to undergo diagnostic evaluation ${ }^{75}$.

In conclusion, we can underline that the shift towards a biological diagnosis of $A D$ involves relevant multi-level challenges against stigma ${ }^{76}$. Consequently, further studies are need.

\section{Ethical consideration}

None.

\section{Acknowledgement}

None.

\section{Funding}

None.

\section{Conflict of interest}

The Authors declare no conflict of interest.

\section{Author contributions}

All the authors contributed in the development of this manuscript.

\section{References}

1 McKhann G, Drachman D, Folstein M, et al. Clinical diagnosis of Alzheimer's disease: report of the NINCDS-ADRDA Work Group under the auspices of Department of Health and Human Services Task Force on Alzheimer's Disease. Neurology 1984;34:939-944. https://doi.org/10.1212/ wnl.34.7.939

2 Dubois B, Feldman $\mathrm{HH}$, Jacova $\mathrm{C}$, et al. Research criteria for the diagnosis of Alzheimer's disease: revising the NINCDS-ADRDA criteria. Lancet Neurol 2007;6:734-746. https://doi.org/10.1016/S1474-4422(07)70178-3

3 Dubois $\mathrm{B}$, Feldman $\mathrm{HH}$, Jacova $\mathrm{C}$, et al. Revising the definition of Alzheimer's disease: a new lexicon. Lancet Neurol 2010;9:1118-1127. https://doi.org/10.1016/ S1474-4422(10)70223-4 
4 Dubois $\mathrm{B}$, Feldman $\mathrm{HH}$, Jacova $\mathrm{C}$, et al. Advancing research diagnostic criteria for Alzheimer's disease: the IWG-2 criteria. Lancet Neurol 2014;13:614-629. https:// doi.org/10.1016/S1474-4422(14)70090-0

5 Jack CR Jr, Knopman DS, Jagust WJ, et al. Hypothetical model of dynamic biomarkers of the Alzheimer's pathological cascade. Lancet Neurol 2010;9:119. https://doi. org/10.1016/S1474-4422(09)70299-6

6 Jack CR Jr, Albert MS, Knopman DS, et al. Introduction to the recommendations from the National Institute on Aging-Alzheimer's Association workgroups on diagnostic guidelines for Alzheimer's disease. Alzheimers Dement 2011;7:257-262. https://doi.org/10.1016/j. jalz.2011.03.004

7 Sperling RA, Aisen PS, Beckett LA, et al. Toward defining the preclinical stages of Alzheimer's disease: recommendations from the National Institute on Aging-Alzheimer's Association workgroups on diagnostic guidelines for Alzheimer's dis- ease. Alzheimer's Dement 2011;7:280-292. https//doi.org/10.1016/j.jalz.2011.03.003

8 Albert MS, DeKosky ST, Dickson D, et al. The diagnosis of mild cognitive impairment due to Alzheimer's disease: recommendations from the National Institute on Aging and Alzheimer's Association workgroups on diagnostic guidelines for Alzheimer's disease. Alzheimer's Dementia 2011;7:270-279. https://doi.org/10.1016/j. jalz.2011.03.008

9 Leitão MJ, Silva-Spinola A, Santana I, et al. Clinical validation of the Lumipulse $\mathrm{G}$ cerebrospinal fluid assays for routine diagnosis of Alzheimer's disease. Alzheimers Res Ther 2019;11:9. https://doi.org/10.1186/s13195-019-0550-8

10 Rosin ER, Blasco D, Pilozzi AR, et al. A narrative review of Alzheimer's disease stigma. J Alzheimers Dis 2020;78:515528. https://doi.org/10.3233/JAD-200932

11 Vanderschaeghe G, Dierickx K, Vandenberghe $R$. Review of the ethical issues of a biomarker-based diagnoses in the early stage of Alzheimer's disease. J Bioeth Inq 2018;15:219-230. https://doi.org/10.1007/ s11673-018-9844-y

12 Smedinga M, Tromp K, Schermer MHN, et al. Ethical arguments concerning the use of Alzheimer's disease biomarkers in individuals with no or mild cognitive impairment: a systematic review and framework for discussion. J Alzheimers Dis 2018;66:1309-1322. https://doi.org/10.3233/ JAD-180638

13 Schermer MHN, Edo R. On the reconceptualization of Alzheimer's disease. Bioethics 2019; 33:138-145. https://doi. org/10.1111/bioe.12516

14 Porteri C, Albanese E, Scerri C, et al. The biomarker-based diagnosis of Alzheimer's disease. 1. Ethical and societal issues. Neurobiol Aging 2017;52:132-140. https://doi. org/10.1016/j.neurobiolaging.2016.07.011

15 Gautier S, Lenzy A, Racine E, et al. Diagnosis and management of Alzheimer's disease: past, present and future ethical issues. Progr Neurobiol 2013;52:132-140.

16 Beauchamp TL, Childress JF. Principle of biomedical ethics. 6 ${ }^{\text {st }}$ Ed. Oxford (UK): Oxford University Press 2009.
17 Kojima G, Taniguchi Y, lliffe S, et al. Frailty as a predictor of Alzheimer disease, vascular dementia, and all dementia among community-dwelling older people: a systematic review and meta-analysis. J Am Med Dir Assoc 2016;17:881 888. https://doi.org/10.1016/j.jamda.2016.05.013

18 Goffman E. Stigma: notes on the management of spoiled identity. NY: Touchstone book 1963.

19 Nguyen T, Li X. Understanding public-stigma and selfstigma in the context of dementia: a systematic review of the global literature. Dementia (London) 2020;19:148-181. https://doi.org/10.1177/1471301218800122

20 Benbow S, Jolley D. Dementia: stigma and its effects. Neurodegenerative disease management 2012;2:165172. https://doi.org/10.2217/nmt.12.7.

21 Mahajan AP, Sayles JN, Patel VA, et al. Stigma in the HIV/ AIDS epidemic: a review of the literature and recommendations for the way forward. AIDS 2008;22(Suppl 2):67-79. https://doi.org/10.1097/01.aids.0000327438.13291.62

22 Milne A. The 'D' word: Reflections on the relationship between stigma, discrimination and dementia, J Ment Health 2010;19:227-233. https://doi. org/10.3109/09638231003728166

23 Thornicroft G, Rose D, Kassam A, et al. Stigma: ignorance, prejudice or discrimination? Br J Psychiatry 2007;190:192 193. https://doi.org/10.1192/bjp.bp.106.025791

24 Mukadam N, Livingston G. Reducing the stigma associated with dementia: approaches and goals. Aging Health 2012;8:377-386. https://doi.org/10.2217/ahe.12.42

25 Corrigan PW, Watson AC. Understanding the impact of stigma on people with mental illness. World Psychiatry 2002;1:16-20.

26 Lasalvia A, Tansella M. Fighting discrimination and stigma against people with mental disorders. Epidemiologia e Psichiatria Sociale 2008;17:1-9. https://doi.org/10.1017/ S1121189X00002608

27 Schomerus G, Lucht M, Holzinger A, et al. The stigma of alcohol dependence compared with other mental disorders: a review of population studies. Alcohol and Alcoholism 2011;46:105-112. https://doi.org/10.1093/alcalc/agq089

28 Angermeyer MC, Matschinger $\mathrm{H}$. Public beliefs about schizophrenia and depression: similarities and differences. Soc Psychiatry Psychiatr Epidemiol 2003;38:526-534. https://doi.org/10.1007/s00127-003-0676-6

29 Thornicroft G. Shunned. Discrimination against people with mental illness. NY: Oxford University Press 2006.

30 Daumerie N, Vasseur Bacle S, Giordana JY, et al. La discrimination vécue par les personnes ayant reçu un diagnostic de troubles schizophréniques. Premiers résultats français de l'étude INDIGO [Discrimination perceived by people with a diagnosis of schizophrenic disorders. INternational study of DIscrimination and stiGma Outcomes (INDIGO): French results]. Encephale 2012;38:224-231. French. https://doi.org/10.1016/j.encep.2011.06.007 
31 Ma R, Mann F, Wang J, Lloyd-Evans B, et al. The effectiveness of interventions for reducing subjective and objective social isolation among people with mental health problems: a systematic review. Soc Psychiatr Epidemiol 2020;55:839876. https://doi.org/10.1007/s00127-019-01800-z

32 Byrne P. Psychiatric stigma: past, passing and to come. J R Soc Med 1997;90:618-621. https://doi. org/10.1177/014107689709001107

33 Rabkin J. Public attitudes towards mental illness: a review of the literature. Schizophrenia Bull 1974;1 (Experimental Issue No.10):9-33.

34 Link BG, Cullen FT, Frank J, et al. The social rejection of former mental patients: Understanding why labels matter. Am J Sociol 1987;92:1461-1500. https://doi. org/10.1086/228672

35 Parcesepe AM, Cabassa LJ. Public stigma of mental illness in the United States: a systematic literature review. Adm Policy Ment Health 2013;40:384-399. https://doi. org/10.1007/s10488-012-0430-z

36 Batsch N, Mittelman MS, and Alzheimer's Disease International (ADI). World Alzheimer Report 2012. Overcoming the stigma of dementia. London: Alzheimer's Disease International 2012.

37 Blay SL, Peluso ETP. Public stigma: the community's tolerance of Alzheimer disease. Am J Geriatr Psychiatry 2010;18:163-171. https://doi.org/10.1097/ JGP.0b013e3181bea900

38 Herrmann LK, Welter E, Leverenz J, et al. Systematic review of dementia-related stigma research: can we move the stigma dial? Am J Geriatr Psychiatry 2018;26:316331. https://doi.org/10.1016/j.jagp.2017.09.006

39 Piver LC, Nubukpo P, Faure A, et al. Describing perceived stigma against Alzheimer's disease in a general population in France: the STIG-MA survey. Int J Geriatr Psychiatry 2013;28:933-938. https://doi.org/10.1002/gps.3903.

40 Cahill S, Clark M, O'Connell $\mathrm{H}$, et al. The attitudes and practices of general practitioners regarding dementia diagnosis in Ireland. Int J Geriatr Psychiatry 2008;23:663-669. https://doi.org/10.1002/gps.1956

41 Werner P. Social distance towards a person with Alzheimer's disease. Int J Geriatr Psychiatry 2005;20:182-188. https://doi.org/10.1002/gps.1268

42 Phillipson L, Magee CA, Jones SC, et al. Correlates of dementia attitudes in a sample of middle-aged Australian adults. Australas J Ageing 2014;33:158-163. https://doi. org/10.1111/j.1741-6612.2012.00624.x

43 von dem Knesebeck O, Angermeyer MC, Lüdecke D, et al. Emotional reactions toward people with dementiaresults of a population survey from Germany. Int Psychogeriatr 2014;26:435-441. https://doi.org/10.1017/ S1041610213002056

44 Justiss MD, Boustani M, Fox C, et al. Patients' attitudes of dementia screening across the Atlantic. Int J Geriatr Psychiatry 2009;24:632-637. https://doi.org/10.1002/ gps. 2173
45 Burgener SC, Buckwalter K, Perkhounkova Y, et al. Perceived stigma in persons with early-stage dementia: longitudinal findings: Part 1. Dementia 2015;14:589-608. https://doi.org/10.1177/1471301213508399

46 Berwald S, Roche M, Adelman S, et al. Black African and Caribbean British Communities' perceptions of memory problems: "We don't do dementia. PloS One 2016;11:e0151878. https://doi.org/10.1371/journal. pone.0151878

47 Stites SD, Rubright JD, Karlawish J. What features of stigma do the public most commonly attribute to Alzheimer's disease dementia? Results of a survey of the U.S. general public. Alzheimer's Dement 2018;14:925-932. https://doi. org/10.1016/j.jalz.2018.01.006

48 Stites SD, Johnson R, Harkins K, et al. Identifiable characteristics and potentially malleable beliefs predict stigmatizing attributions toward persons with Alzheimer's disease dementia: results of a survey of the U.S. general public. Health Commun 2018;33:264-273. https://doi.org/10.10 80/10410236.2016.1255847

49 Alzheimer's Disease International (ADI). World Alzheimer Report 2019: attitudes to dementia. London: Alzheimer's Disease International 2019.

50 Alzheimer's Australia. Dementia and the impact of stigma. Alzheimer's Australian report 2017 (www.dementia.org.au [accessed November 25, 2020]).

51 Davidson M, Schnaider B. Costs of Alzheimer's disease. Dialogues Clin Neurosci 2000;2:157-161. https://doi. org/10.31887/DCNS.2000.2.2/mdavidson

52 Behuniak SM. The living death? The construction of people with Alzheimer's disease as zombies. Aging Soc 2011;31:70-92. https://doi.org/10.1017/ S0144686X10000693

53 Weiner B, Perry RP, Magnusson J. An attributional analysis of reactions to stigmas. J Pers Soc Psychol 1988;55:738748. https://doi.org/10.1037//0022-3514.55.5.738

54 Liu, P, Xie Y, Meng X. et al. History and progress of hypotheses and clinical trials for Alzheimer's disease. Sig Transduct Target Ther 2019;4:29. https://doi.org/10.1038/ s41392-019-0063-8

55 Bennett DA, Schneider JA, Arvanitakis Z, et al. Neuropathology of older persons without cognitive impairment from two community-based studies. Neurology 2006;66:1837-1844. https://doi.org/10.1212/01. wnl.0000219668.47116.e6

56 Jansen WJ, Ossenkoppele R, Knol DL, et al. Prevalence of cerebral amyloid pathology in persons without dementia: a meta-analysis. JAMA 2015;313:1924-1938. https://doi. org/10.1001/jama.2015.4668

57 Poveda AM. An anthropological perspective of Alzheimer disease. Geriatric Nursing 2003;24:26-31. https://doi. org/10.1067/mgn.2003.15

58 Wimo A, Handels R, Winblad B, et al. Quantifying and describing the natural history and costs of Alzheimer's disease and effects of hypothetical interventions. J Alzheimers Dis 2020;75:891-902. https://doi.org/10.3233/ JAD-191055 
59 Richeson JA, Shelton JN. A social psychological perspective on the stigmatization of older adults. In: Carstensen LL, Hartel CR, Eds. National Research Council (US) Committee on aging frontiers in social psychology, personality, and adult developmental psychology. When I'm 64. Washington (DC): National Academies Press (US) 2006 ( https:// www.ncbi.nlm.nih.gov/books/NBK83758).

60 Alpinar-Sencan Z, Schicktanz S. Addressing ethical challenges of disclosure in dementia prediction: limitations of current guidelines and suggestions to proceed. BMC Medical Ethics 2020;21:33. https://doi.org/10.1186/ s12910-020-00476-4

61 Guerra UP, Nobili FM, Padovani A, et al. Recommendations from the Italian Interdisciplinary Working Group (AIMN, AIP, SINDEM) for the utilization of amyloid imaging in clinical practice. Neurol Sci 2015;36:1075-1081. https:// doi.org/10.1007/s10072-015-2079-3

62 Padovani A, Musicco M, Caltagirone C, et al. Raccomandazioni dell'Associazione Italiana di Psicogeriatria (AIP) e della Società Italiana Neurologia delle Demenze (SINDEM) sulla diagnosi precoce della malattia di Alzheimer. [Recommendations of the Italian Psychogeriatric Association (AIP) and Italian Society for the Study of Dementia (SINDEM) on early diagnosis of Alzheimer disease]. Psicogeriatria 2015:5-56.

63 Petersen RC, Lopez O, Armstrong MJ, et al. Practice guideline update summary: mild cognitive impairment: report of the guideline development, dissemination, and implementation. Subcommittee of the American Academy of neurology. Neurology 2018;90:126-135. https://doi. org/10.1212/WNL.0000000000004826

64 Gauthier S, Patterson C, Chertkow H, et al. Recommendations of the $4^{\text {th }}$ Canadian consensus conference on the diagnosis and treatment of dementia (CCCDTD4). Can Geriatr J 2012;15:120-126. https://doi.org/10.5770/cgj.15.49

65 Deuschl G, Maier W. S3-Leitlinie "Demenzen" Langversion. In: Gesellschaft EV, Ed. Zusammenarbeit mit der deutschen Alzheimer. Deutsche Gesellschaft für Psychiatrie und Psychotherapie, Psychosomatik und Nervenheilkunde (DGPPN), Deutsche Gesellschaft für Neurologie (DGN) 2016 (https://www.awmf.org/uploads/tx_szleitlinien/038-013I_ S3-Demenzen-2016-07.pdf [Accessed 10 June 2019])

66 Ad Hoc Working Group in the German Stakeholder Conference on Conflicts in Predictive Dementia Diagnostics. Consensual Position Statement. Göttingen/Bochum: Department of Medical Ethics and History of Medicine of the University Medical Center Göttingen and IEGUS - Institut für europäische Gesundheits- und Sozialwirtschaft, 2018.
67 Galimberti D, Scarpini E. Disease-modifying treatments for Alzheimer's disease. Ther Adv Neurol Disord 2011;4:203216. https://doi.org/10.1177/1756285611404470

68 Kim S, Werner P, Richardson A, et al. Dementia Stigma Reduction (DESeRvE): study protocol for a randomized controlled trial of an online intervention program to reduce dementia-related public stigma. Contemp Clin Trials Commun 2019;14:100351. https://doi.org/10.1016/j. conctc. 2019.100351

69 Morgan AJ, Reavley NJ, Ross A, et al. Interventions to reduce stigma towards people with severe mental illness: systematic review and meta-analysis. J Psychiatr Res 2018;103:120-133. https://doi.org/10.1016/j. jpsychires.2018.05.017

70 Bienvenu B, Hanna G. Arts participation: counterbalancing forces to the social stigma of a dementia diagnosis. AMA J Ethics 2017;19:704-712. https://doi.org/10.1001/journalo fethics.2017.19.7.msoc2-1707

71 Swinnen A, de Medeiros K. Participatory arts programs in residential dementia care: playing with language differences. Dementia (London) 2018;17:763-774. https://doi. org/10.1177/1471301217729985

72 Fazio S, Pace D, Flinner J. et al. The fundamentals of person-centered care for individuals with dementia. The Gerontologist 2018;58:S10-S19. https://doi.org/10.1093/ geront/gnx122

73 Yang LH, Anglin DM, Wonpat-Borja AJ, et al. Public stigma associated with psychosis risk syndrome in a college population: implications for peer intervention. Psychiatr Serv 2013;64:284-288. https://doi.org/10.1176/appi. ps.003782011

74 Karlawish J. Addressing the ethical, policy, and social challenges of preclinical Alzheimer disease. Neurology 2011;77:1487-1493. https://doi.org/10.1212/ WNL.0b013e318232ac1a

75 Fowler NR, Frame A, Perkins AJ, et al. Traits of patients who screen positive for dementia and refuse diagnostic assessment. Alzheimers Dement (Amst) 2015;1:236-241. https://doi.org/10.1016/j.dadm.2015.01.002

76 Chao S, Roberts JS, Marteau TM, et al. Health behavior changes after genetic risk assessment for Alzheimer disease: the REVEAL Study. Alzheimer Dis Assoc Disord 2008;22:94-97. https://doi.org/10.1097/ WAD.0b013e31815a9dcc 